\title{
Site Suitability Analysis for Cork Oak Regeneration Using GIS Based Multicriteria Evaluation Techniques in Maamora Forest-Morocco
}

\author{
Bawinabadi M. Bagaram ${ }^{1}$, Fouad Mounir ${ }^{1}$, Saïd Lahssini ${ }^{1}$, Quentin Ponette ${ }^{2}$ \\ ${ }^{1}$ National School of Forestry Engineering, Tabriquet, Morocco \\ ${ }^{2}$ Catholic University of Louvain, Louvain la Neuve, Belgium \\ Email: "martinobag@gmail.com
}

Received 2 March 2016; accepted 19 March 2016; published 22 March 2016

Copyright (C) 2016 by authors and OALib.

This work is licensed under the Creative Commons Attribution International License (CC BY). http://creativecommons.org/licenses/by/4.0/

(c) (i) Open Access

\begin{abstract}
Following the assumption that some soils are less suitable for the development of cork oak, a substitution of cork oak by exotic species has been carried out on a large part of Maamora forest. However, soil is not the only factor to consider in assessing the suitability. Therefore, some areas might just suit to cork oak but to what extent? To answer this question, major factors known to influence the regeneration of cork oak have been identified and mapped using multicriteria evaluation. Therefore, factors were incorporated by weighted linear combination to determine suitability indices for the regeneration of cork oak. The weight of each factor was estimated by expert judgment using the AHP (Analytic Hierarchy Process) approach. The main factors influencing the cork oak regeneration suitability in Maamora forest are climate expressed by "continentality", terrainslope, thickness of the sand, slope of the clay floor layer, and plant communities and soil types. These factors were mapped by incorporating fuzzy logic in order to avoid crisp classes and ensure a smooth transition between the preference and indifference. This allowed then to integrate uncertainty in the knowledge of the exact class limits. Finally, four classes of regeneration suitability were obtained. These classes are good, medium, low and very low suitability and which represent $17.40 \%, 40.18 \%, 34.84 \%$ and $4.28 \%$ of the forest area respectively.
\end{abstract}

\section{Keywords}

Fuzzy Logic, Analytic Hierarchy Process (AHP), Weighted Linear Combination (WLC), Spatial Analysis, Maâmora

Subject Areas: Ecosystem Science, Environmental Sciences

\footnotetext{
${ }^{*}$ Corresponding author.
}

How to cite this paper: Bagaram, B.M., Mounir, F., Lahssini, S. and Ponette, Q. (2016) Site Suitability Analysis for Cork Oak Regeneration Using GIS Based Multicriteria Evaluation Techniques in Maamora Forest-Morocco. Open Access Library Journal, 3: e2483. http://dx.doi.org/10.4236/oalib.1102483 


\section{Introduction}

Maamora is considered the largest cork oak forest in the world that is in one piece with an area of 131,738 ha. It consists of about 60,000 ha of cork oak, the rest of the surface is occupied by the introduced species [1]. Due to its diversity and its proximity to major cities, Maamora’s forest plays a very important economic, environmental and social function [2]. Regeneration is a key factor in forest conservation and mitigation of deficit in wood products. This activity is based among other things for its success on a perfect knowledge of the fitness stations. Ignorance of this factor would probably lead to the failure of reforestation and regeneration and loss of funds and efforts for their realization. Despite the efforts of forest manager, cork oak regeneration remains capricious and planning studies that have followed show a down ward trend estimated at about $30 \%$ of the surface of the cork oak [3]. The station identification is a fundamental step in the choice of regeneration schemes.

Moreover, evaluating land suitability for plantation purposes aims to predict lands which fit well for a species according to specified requirements, preferences, or predictors values [4]. It requires paying attention to four aspects: 1) biophysical attributes which will dictate growth ability and productivity level (mainly climate, soil and terrain), 2) economic aspects which impact plantation profitability (markets, infrastructure, operations scale, etc...), 3) social impact on local inhabitant and 4) environmental assessment [5]. In addition, forest site quality could be defined "as the physical and biological factors that characterize a site's ability to support tree growth" [6]. At large scale, methods known as "climate envelope models" [7] [8] may be very useful. Such models are based on the assumption that a species may grow adequately anywhere that the climate is similar to that of the region where the species occurs naturally [9]. Forest site is influenced by a complex array of factors and could be defined both qualitatively and quantitatively [10]. By nature, land suitability and site quality are a multiple criteria problem.

Even though many studies on land suitability are conducted in agriculture [11]-[13], there are few in forestry. The land suitability methods are diverse and range from random forest [14], GIS techniques [15] [16], fuzzy logic [17] and AHP [12] but few authors used the integrated approach combining GIS (multicriteria analysis), fuzzy logic and AHP in the same study even though according to Zang et al. [11], the integrated approach has a great potential to increase the effectiveness and accuracy of land suitability assessment.

The use of AHP coupled with fuzzy logic and multi-criteria assessment of the suitability of cork oak stands regeneration Maamora would locate with high potential for the development of young stands of cork oak leading to a greater chance of success of the work of regeneration proposed in this forest. Then this paper work aims to assess the extent of suitable areas to cork oak regeneration and serves as decision support tool for forest managers.

\section{Materials and Methods}

\subsection{Study Area}

Maamora forest is located in north-west of Morocco, bordering the Atlantic Ocean, between the meridians $6^{\circ}$ and $6^{\circ} 45^{\prime}$ West and parallel $34^{\circ}$ and $34^{\circ} 20^{\prime}$ north. The bioclimate is sub humid in the western part and semi-arid in the central and eastern part of the forest. Maamora offers a multitude of goods and services (60,000 cubic meters of cork per year, 100,000 cubic meters of firewood/year, 21 million feed units/year, revenues in excess of 70 million dirhams, recreation space for the population of nearby towns, the role of protection of soil and groundwater supply, etc.) (Figure 1).

\subsection{Methodological Approach}

The first part is devoted to a literature review to identify factors known to influence the regeneration of cork oak. These factors once identified, were mapped. The multicriteria evaluation approach is the one that was used for the evaluation of the suitability of cork oak regeneration. Therefore, factors were combined using a weighted linear combination (WLC). The weight of each factor is determined from the AHP (Analytic Process hierarchy). In order to have representative weight, three experts working on three different aspects of Maamora forest management were consulted.

AHP is a method developed by Saaty [18]. It is based on a comparison of factors in pairs by experts with knowledge on the functioning of the system studied. This method has the advantage of refining the decision-making process by examining the coherence and consistency of decision-makers [19]. The starting point of 


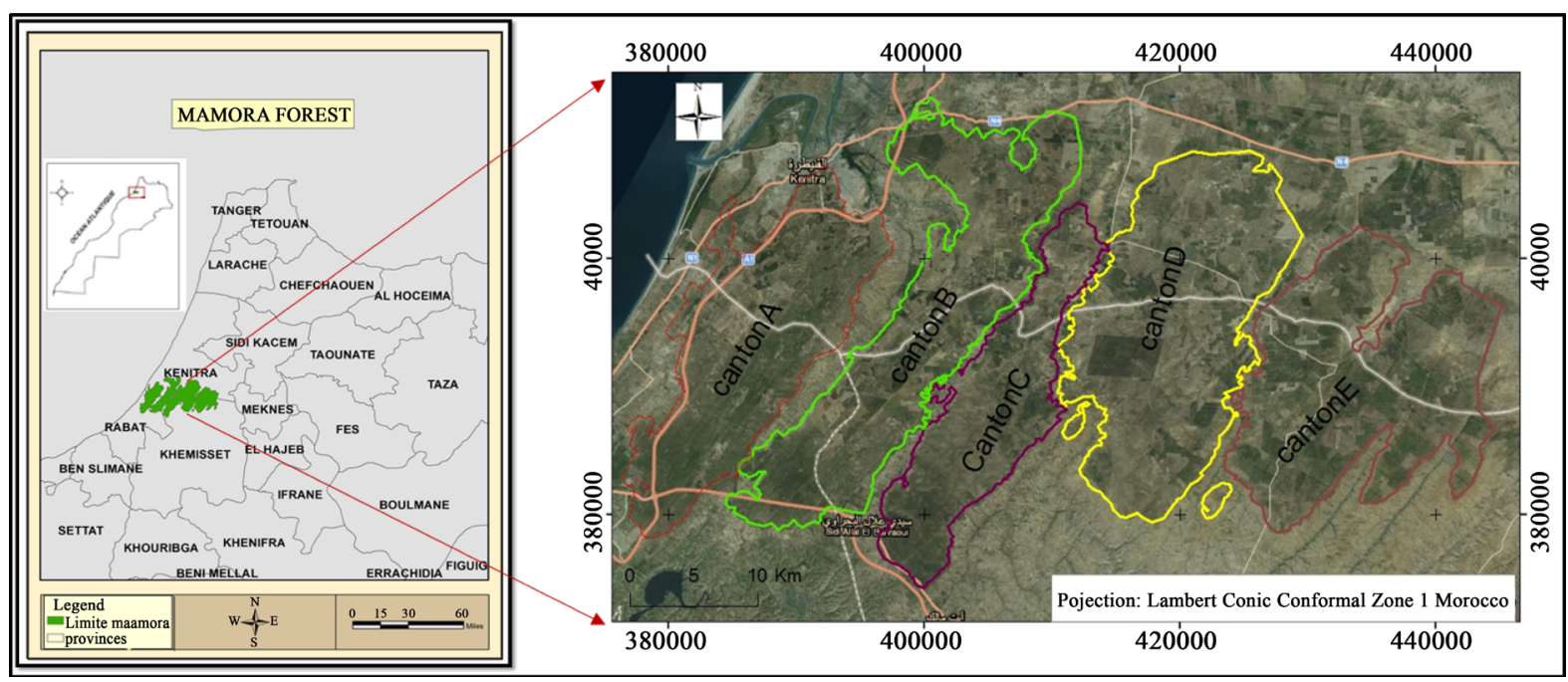

Figure 1. Map of the location of the Maamora forest (with google earth basemap).

the method is to define a hierarchical tree of criteria and sub-criteria. Representation of the tree is in the form of father-son pairs.

To integrate the various factors identified, it is necessary to codify digitally qualitative data. Then factors were standardized (or normalized) on the same scale. The scale chosen for this study is a scale of values ranging from 0 to 1 . A value of 1 corresponds to the class best suited for the regeneration of cork oak vis-à-vis to the factor considered and the value 0 for class less favorable. Similarly, to incorporate the uncertainty of class boundaries and at the same time avoid having classes with sharp breaks, classes were defined based on fuzzy rules ("fuzzy logic"). These GIS analyzes were performed using Quantum GIS (Qgis).

\subsubsection{Factors and Constraints Considered in the Evaluation}

Criteria or factors taken into account are those considered affecting the regeneration of cork oak. According to Godard [20], the constraints are the Boolean criteria that limit the analysis to specific regions. Regardless of the method used eventually for aggregation of criteria, constraints are always Boolean images. In the case of this study, the constraints differentiate areas that are classified as suitable for the development of forest trees from those that are considered unfit, whatever the conditions. In contrast, the factors are criteria that define a degree of suitability for all regions. They define areas of fitness, or alternatives, which are expressed by continuous values.

\subsubsection{Determination of Score of Each Criterion}

It is a convenient way to map each of the factors identified as important in the suitability for the regeneration of the Cork oak in Maamora. In this study case, Heusch \& Billaux [21] have developed map of soil types. The map of bare soil slopes is derived from a digital elevation model (DEM) ASTER, "continentality" is expressed by the hysohyet curves developed by Mandouri [22], and Bagaram [23] has given the sand's thickness and clay floor slope maps.

Then these factors were standardized to ensure all criteria are in the same range. Many authors advise to use a scale of values ranging from 0 to 1 with 0 corresponding to the area that are unsuitable for the purpose regarding to the factor and 1 for best areas [11]. For this purpose, it is important to decide on the membership function using fuzzy rules. The choice of the membership function depends on the criterion and the knowledge of its variation by the experts [24]. However, a sigmoid function (S-shaped) is the most used in the natural resources [25].

In this work, the factors have been standardized on a scale of 0 to 1 . The choice of the score for each class is based on the results of the literature review. A class for a given factor will receive a high score if this class contributed effectively to the regeneration of the Cork oak.

\subsubsection{Allocation of Weight to Each of the Factors}

The AHP was the technique used for weighting factors. To achieve relevant weights, three experts in the forest of Maamora with different areas of strength were contacted. This method has the advantage to refine the deci- 
sion-making process by examining the coherence and logic of decision makers [19]. The starting point of the method is to define a hierarchical tree view of criteria and sub-criteria. The tree representation is in the form of father-son pairs.

\subsubsection{AHP Process Description}

This method developed by Saaty [18], is based on the comparison of pair of factors by experts with a knowledge on the functioning of the system (Figure 2). This method has the advantage to refine the decision-making process by examining the coherence and logic of decision makers [19]. The starting point of the method is to define a hierarchical tree view of criteria and sub-criteria. The tree representation is in the form of father-son pairs. Three 'experts' in the Maamora forest management compared all factors considered important in the regeneration of cork oak two by two. The criteria are compared on a scale of 1 to 9 as recommended by Saaty \& Vargas [26]; where 1 means there is no preference between the two criteria and 9 means a factor is extremely favored over another. This produces a squared matrix where the rows and columns are the criteria.

Subsequently, the factors are classified by considering their weight. These weights are obtained using the Eigen vector called priority vector. The Eigen vector is determined by calculating the average of the values in the rows of the matrix. For Standardization, the value of each cell was divided by the total of each column.

Although the comparison of matrix pairs is not assigned randomly, there may still be an inconsistency due to the opinions and preferences of experts. This inconsistency may cause a disturbance in the calculation of the weight (of the eigen values of the matrix). These inconsistencies can be of the form that a factor is preferred to the detriment of another one, which in turn is preferred over a third, but there is no transitivity between the factors.

To compensate for this, the Consistency Ratio (CR) proposed by Saaty [18] was calculated. This is the ratio of the Consistency Index (CI) over the Random consistency index (RI).

$$
\mathrm{CR}=\frac{\mathrm{CI}}{\mathrm{RI}}
$$

The abacus of Saaty\& Vargas [26] gives the Random consistency index (RI). This index is given for a squared matrix up to an order of 15 (i.e. 15 factors) (Table 1).

The consistency index (CI) was directly calculated from the preferences matrix as Saaty [18] recommended in formula (2):

$$
\mathrm{CI}=\frac{\lambda_{\max }-n}{n-1}
$$

with

$\lambda_{\max }:$ principale eigen value of the preference matrix.

n: number of factors.

Saaty \& Vargas [26] require that the matrix of preferences must be rechecked if Consistency Ratio (CR) is greater than 0.1 .

\subsubsection{Aggregation or Combination of Weight and Notes for a Synthetic Result}

It comes here to combine the factors by assigning their weight and then summing them to get the suitability map.

\begin{tabular}{|c|c|c|c|c|c|c|c|}
\hline $1 / 7$ & $1 / 5$ & $1 / 3$ & 1 & 3 & 5 & 7 & 9 \\
\hline $\begin{array}{l}\text { Extreme } \quad \text { Very strong } \\
\text { factor } A<\text { factor } B\end{array}$ & Strong & Moderate & Equal & Moderate & Strong & $\begin{array}{l}\text { Very strong } \\
\text { factor } B>\end{array}$ & $\begin{array}{l}\text { extreme } \\
\text { actor } A\end{array}$ \\
\hline
\end{tabular}
This is done under the following expression:

Figure 2. Scale of Saaty [18] for the ponderation of factors by pair.

Table 1. RI Values de avec $\mathrm{n}=$ number of factors.

\begin{tabular}{cccccccccccccccccccc}
\hline $\mathrm{n}$ & 1 & 2 & 3 & 4 & 5 & 6 & 7 & 8 & 9 & 10 & 11 & 12 & 13 & 14 & 15 \\
$\mathrm{R} .1$ & 0.00 & 0.00 & 0.58 & 0.90 & 1.12 & 1.24 & 1.32 & 1.41 & 1.45 & 1.49 & 1.51 & 1.54 & 1.56 & 1.57 & 1.59 \\
\hline
\end{tabular}

According to Saaty \& Vargas [26]. 


$$
S=\sum_{i} W_{i} X_{i} \prod_{j} C_{j}
$$

with

S: suitability composite score.

$W_{i}:$ weight assigned to the factor $i$.

$X_{i}$ : score of the factor $i$.

$C_{j}$ : contraint jscore (0 ou 1$)$.

The final result (as a map) was classified into four classes of suitability and then the majority of pixels belonging to any class within a parcel is taken as the suitability of that parcel.

\section{Results and Discussions}

Factors influencing the regeneration of cork oak in the forest of Maamora climate are expressed by the term "continentality" which translates to reduced rainfall and increased temperatures in the west to the east of the forest, topo-édaphie (depth of clay floor and the slope of the clay floor), the slope of the natural terrain namely gentle slopes $(<10 \%)$ and steep slopes $(>15 \%)$, plant communities and soil types.

The cork oak regeneration suitability regard to the depth of the clay floor (sand's thickness) was evaluated by splitting depth data into homogeneous areas. These areas are the Western Maamora (Canton A and B), the Central Maamora (Canton C) and the Eastern Maamora (Canton D and E). The depth considered suitable for cork oak was assessed using the fuzzy rules in establishing a membership function. This allowed then to incorporate uncertainty about the exact depth of the clay floor suitable for cork oak regeneration. The membership functions defined are in Figure 3.

For example, in "Mamoraoccidentale" (Figure 3), depth of $50 \mathrm{~cm}$ is considered too shallow while a sand thickness of $80 \mathrm{~cm}$ is considered deep enough for cork oak development. Thus, areas with a sand's thickness situated between the two limits have a range of suitability ranging from 0 to 1 . The optimal sand's thickness is between $80 \mathrm{~cm}$ and less than $190 \mathrm{~cm}$ corresponding to the highest suitability. Beyond a depth of $250 \mathrm{~cm}$, the sand is considered too thick and therefore areas with that sand's thickness have a suitability of 0 .

As for the depth of the clay floor, slopes favorable to the regeneration of the Cork oak can be defined. To incorporate also the uncertainty associated with the limit of the classes, the following membership functions have been defined (Figure 4). In "Maamoracentrale" and "Maamoraorientale", average clay floor slopes are those that suit for cork oak development [27]. For instance, clay floor slopes ranging from 3\% to $12 \%$ are the one suitable for cork oak optimal development in Maamora central while clay floor slopes greater than $15 \%$ are considered too steep and then received a suitability of 0 (Figure 4). Because clay floor slope's is not considered as a main factor influencing cork oak regeneration in "Mamoraoccidentale" [27], there is no membership function defined for that part of the forest.

Since the slope and the depth of the clay floor are related factors, and therefore the scores of one depends on the other, these two factors have been combined by an 'AND' condition. This resulted in a new factor referred to as the topo-edaphic factor uniting both the thickness of sand and the slope of the clay floor conditions.

Analysis of mapped soil types leaves see that there are different types of soils whose contribution to the regeneration of cork oak differs. Thus, the lowest scores are given unfavorable to the Cork oak floors (hydromorphic soils and little advanced soil) while high scores are reserved for best-judged soil (Figure 5).

To discriminate against very strong deemed slopes that are not suitable for the regeneration of the Cork oak, a membership function has been defined. A slope is considered high when it is greater than $15 \%$ and low when it is less than 10\%. Figure 6 represents the membership function.

Because in Maamora is the variation of precipitation which is recognized have a significant effect on the regeneration of cork oak, it is only this setting is taken into account to assess the effect of continentality on regeneration. Continentality scores are evaluated using the interpolated curves of isohyets anywhere in the forest with the minimum of precipitation with a score of 0 and a maximum score of 1 ; These scores are given a linear function.

Comparison of factors by the experts allowed to generate the coefficients of weighting for each factor (Table 2). Experts believe that the overriding factor in the regeneration of the Cork oak in Maamora is the climatic factor (42\%) including precipitation of the fact that the forest is located in the lower limit of the range of the Cork oak. The least important factor is the slope of the ground with a weight of $12 \%$ and this because Maamora is not a mountainous forest. Indeed, Maamora is located in a plaine where slopes are gentle and shorts. 

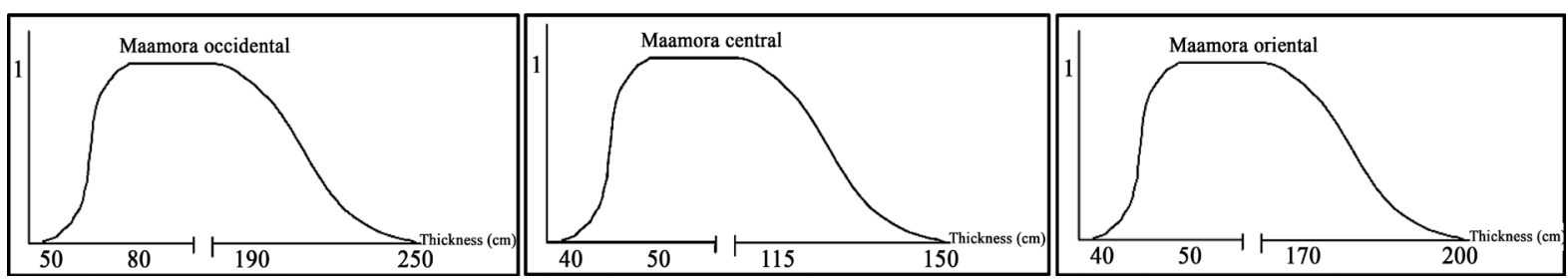

Figure 3. Membership functions for score attribution to the sand's thickness factor. On the Y axis, is the suitability with 1 referring to maximum suitability for cork oak regeneration and the $\mathrm{x}$ axis represent the sand's thickness in centimeters.
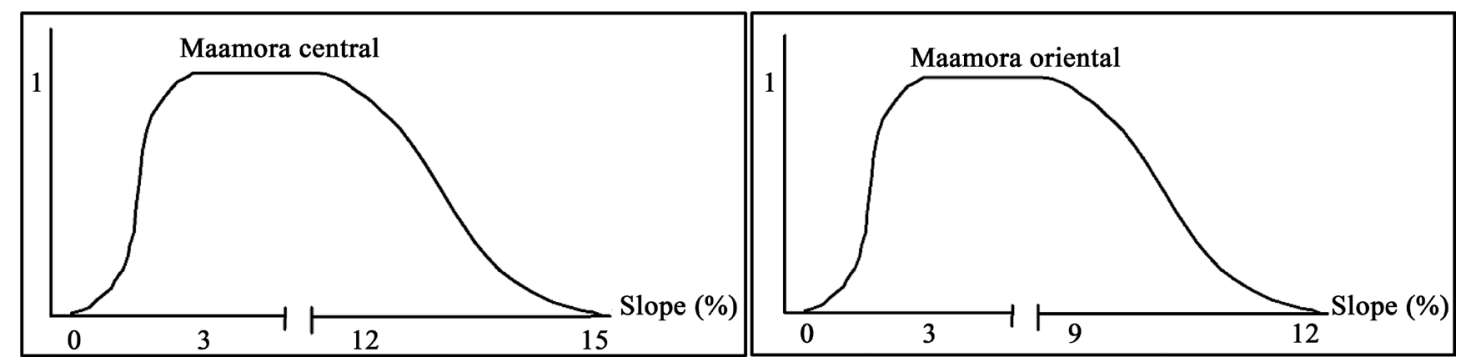

Figure 4. Membership functions for score attribution to the clay floor slope's factor. On the Y axis, is the suitability with 1 referring to maximum suitability for cork oak regeneration and the $\mathrm{x}$ axis represent the clay floor slope in percentage.

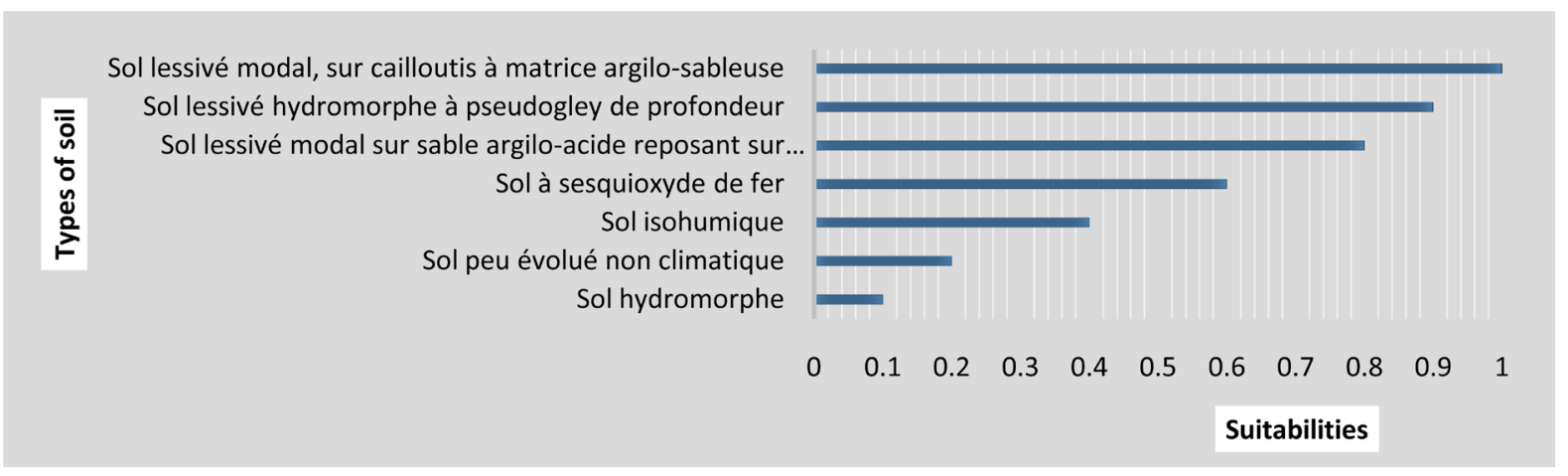

Figure 5. Suitability regard to cork oak regeneration of different soil types in Maamora forest.

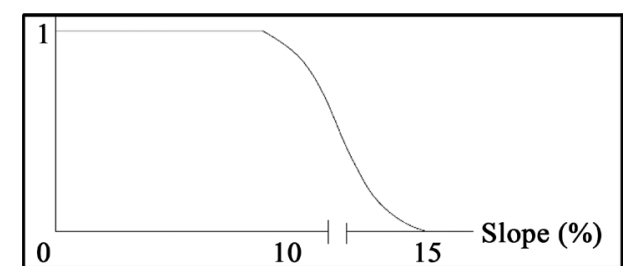

Figure 6. Membership functions for score attribution to the bare soil slope's factor. On the Y axis, is the suitability with 1 referring to maximum suitability for cork oak regeneration and the $\mathrm{x}$ axis represent the bare soil slope in percentage.

Table 2. Summary of the weight given by experts.

\begin{tabular}{cccccccc}
\hline \multirow{2}{*}{ Experts } & \multicolumn{9}{c}{ Criteria } & \multicolumn{2}{c}{ CI } & CR (\%) \\
\cline { 2 - 5 } & Topo-edaphic & Continentality & Bare soil slope & Types of soil & & \\
1 & 0.29 & 0.41 & 0.05 & 0.25 & 0.07 & 7 \\
2 & 0.24 & 0.61 & 0.06 & 0.09 & 0.05 & 5 \\
3 & 0.25 & 0.25 & 0.25 & 0.25 & 0 & 0 \\
Average & $\mathbf{0 . 2 6}$ & $\mathbf{0 . 4 2}$ & $\mathbf{0 . 1 2}$ & $\mathbf{0 . 2 0}$ & $\mathbf{0 . 0 4}$ & $\mathbf{4}$ \\
\hline
\end{tabular}

$\mathrm{RI}=$ Random consistancy index, $\mathrm{CR}=$ Consitancy ratio. 
After aggregation of factors, indices of suitability are grouped into four equal intervals. The highest indices correspond to the best ability and vice versa (Figure 7). Around 23,400 ha or $17.4 \%$ of the forest are areas with good suitability for regeneration of cork oak while $34.84 \%$ forest representing an area of $46,881.81$ ha is poorly suited to regeneration of cork oak (Figure 8).

There is a gradient even though nonlinear in the success rate of plantation from west to east. The highest success rates are in the west part of the forest (canton A and B). These results confirms those obtained by other authors [28] [29]; showing a decrease in the success rates of plantation from forest's west to its east. In this study, the results are mainly influenced by soil and climate factors due to the importance the experts gave to those factors. This might be the main weakness of the AHP where the is a subjective attribution of the weight of factors.

\section{Conclusion}

This study provided to forest managers a tool for selection of priority areas in which regeneration could be considered. The result aggregated on the scale of forest parcel is very useful since it is the forest management unit. It shows as well that not all the adjacent areas have the same suitability. Multi-criteria assessment is a simple but yet very effective technique that can be used in the assessment of suitability for the reforestation of many species in the Maamora forest. The method is more robust when associated with fuzzy logic and AHP. However, this map does not guaranty systematically the success of the regeneration as this depends itself on the availability of seeds, precipitations, and nonetheless, human factors like grazing, acorn collection and a good silvicultural practice.

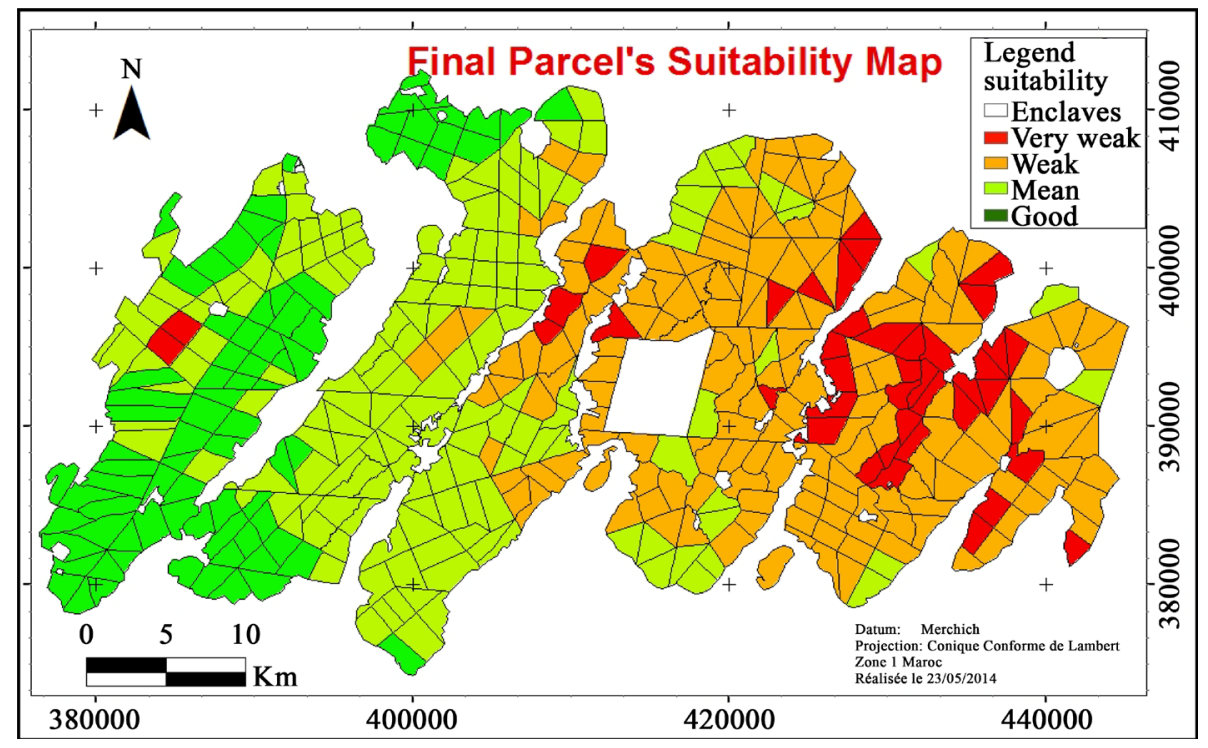

Figure 7. Map of the average regeneration suitability of cork oak by parcel in the Maamora forest.

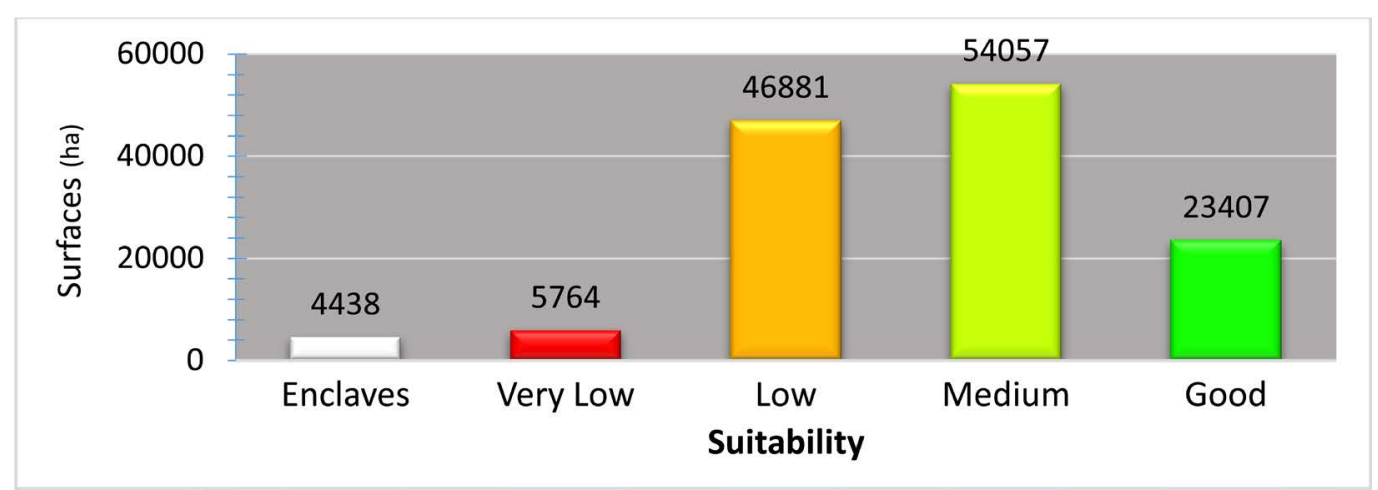

Figure 8. Area in hectares for different suitability levels. 


\section{Acknowledgements}

This research was financially supported by the Wallonie Bruxelle international, within the scope of the granted project “Comportement des plantations du chêneliège de la forêt de Maamora, Maroc”.

\section{References}

[1] HCEFLCD (2011) Aménagement proposé, PV d’aménagement de la forêt de la Maâmora, Rabat.

[2] Benzyane, M. (1996) L’aménagement forestier: Concept et évolution. Le grand livre de la forêt marocaine. Mardaga, 126-144.

[3] Mounir, F. (2002) Conception d'un système d'information géographique pour l'aménagement et la gestion forestière au Maroc; Intégration des critères et indicateurs du dévelopement durable; Application à la forêt de la Maâmora. Thèse de Doctorat, UCL, Belgique.

[4] Collins, M.G., Steiner, F.R. and Rushman, M.J. (2001) Land-Use Suitability Analysis in the United States: Historical Development and Promising Technological Achievements. Environmental Management, 28, 611-621. http://dx.doi.org/10.1007/s002670010247

[5] Shepherd, K.R. (1986) Plantation Sylviculture. Kluwer Academic Publishers, 322 p. http://dx.doi.org/10.1007/978-94-009-4446-6

[6] Skovsgaard, J.P. and Vanclay, J.K. (2008) Forest Site Productivity: A Review of the Evolution of Dendrometric Concepts for Even-Aged Stands. Forestry, 81, 13-31. http://dx.doi.org/10.1093/forestry/cpm041

[7] Hijmans, R.J. and Graham, C.H. (2006) The Ability of Climate Envelope Models to Predict the Effect of Climate Change on Species Distributions. Global Change Biologie, 12, 2272-2281. http://dx.doi.org/10.1111/j.1365-2486.2006.01256.x

[8] Pearson, R.G., Thuiller, W., Araújo, M.B., Martinez-Meyer, E., Brotons, L., Miles, L., Segurado, P., Dawson, T.P. and Lees, D.C. (2006) Model-Based Uncertainty in Species Range Prediction. Journal of Biogeographie, 33, 1704-1711. http://dx.doi.org/10.1111/j.1365-2699.2006.01460.x

[9] West, P. (2014) Growing Plantation Forests. Springer. http://dx.doi.org/10.1007/978-3-319-01827-0

[10] Weiskittel, A.R., Hann, D.W., Kershaw, J.J.A. and Vanclay, J.K. (2011) Forest Growth and Yield Modeling. John Wiley and Sons. http://dx.doi.org/10.1002/9781119998518

[11] Zhang, J., Su, Y., Wu, J. and Liang, H. (2015) GIS Based Land Suitability Assessment for Tobacco Production Using AHP and Fuzzy Set in Shandong Province of China. Computers and Electronics in Agriculture, 114, 202-211. http://dx.doi.org/10.1016/j.compag.2015.04.004

[12] Akıncı, H., Özalp, A.Y. and Turgut, B. (2013) Agricultural Land Use Suitability Analysis Using GIS and AHP Technique. Computers and Electronics in Agriculture, 97, 71-82. http://dx.doi.org/10.1016/j.compag.2013.07.006

[13] Elsheikh, R., Mohamed Shariff, A.R.B., Amiri, F., Ahmad, N.B., Balasundram, S.K. and Soom, M.A.M. (2013) Agriculture Land Suitability Evaluator (ALSE): A Decision and Planning Support Tool for Tropical and Subtropical Crops. Computers and Electronics in Agriculture, 93, 98-110. http://dx.doi.org/10.1016/j.compag.2013.02.003

[14] Lahssini, S., Lahlaoi, H., Mharzi Alaoui, H., Hlal, E.A., Bagaram, M. and Ponette, Q. (2015) Predicting Cork Oak Suitability in Maâmora Forest Using Random Forest Algorithm. Journal of Geographic Information System, 7, $202-210$. http://dx.doi.org/10.4236/jgis.2015.72017

[15] Chen, H.S. (2013) Evaluation of Soil Fertility Suitability of Tobacco Planting Fields on Slant Plain in the East Side of Funiushan Mountainin at Central China Supported by GIS. Journal of Food Agriculture and Environment, 11, 14591463.

[16] Davis, H.T., Aelion, C.M., McDermott, S. and Lawson, A.B. (2009) Identifying Natural and Anthropogenic Sources of Metals in Urban and Rural Soils Using GIS-Based Data, PCA, and Spatial Interpolation. Environmental Pollution, 157, 2378-2385. http://dx.doi.org/10.1016/j.envpol.2009.03.021

[17] Keshavarzi, A. (2010) Land Suitability Evaluation Using Fuzzy Continuous Classification (A Case Study: Ziaran Region). Modern Applied Science, 4, 10. http://dx.doi.org/10.5539/mas.v4n7p72

[18] Saaty, T.L. (1977) A Scaling Method for Priorities in Hierarchical Structures. Journal of Mathematical Psychology, 231-281. http://dx.doi.org/10.1016/0022-2496(77)90033-5

[19] Caillet, R. (2003) Analyse multicritère: Analyse et comparaison de méthodesexistantes en vue d'une application en vue d'une application analyse de cycle de vie. CIRANO, Montreal, 53.

[20] Godard, V. (2007) Cours de Master. Aide à la décision et SIG, Paris.

[21] Heusch, B. and Billaux, P. (1966) Carte pédologique du Rharb, de la Maâmora Septentrionale et de leur bordure 
orientale.

[22] Mandouri, T. (1990) Importance de la fertilisation dans le fonctionnement de l'écosystème à Eucalyptus (Lacke albacutya) avec et sans fertilisation en milieu sableux et en climat méditerranéen du Maroc.

[23] Bagaram, B.M. (2014) Elaboration d’une base de données géographique et catalogue des stations de la subéraie de la Maâmora. Memoire du 3ème Cycle, ENFI, Salé, Morocco.

[24] Estoque, R.C. (2011) GIS-Based Multi-Criteria Decision Analysis (inn Naturall Resources Management).

[25] Eastman, J.R. (2004) Système d’Information Géographique et aide à la décision. IDRISI 4.1 Update Manual, Clark University.

[26] Saaty, T.L. and Vargas, L.G. (1991) Prediction, Projection and Forecasting. Kluwer Academic Publisher, Dordrecht, 251 p. http://dx.doi.org/10.1007/978-94-015-7952-0

[27] Lepoutre, B. (1965) Régénération artificielle du chêne-liège et équilibre climatique de la suberaie de la forêt en forêt de la Maâmora. Annale de la Recherche Forestière, Maroc.

[28] Belghazi, B., Badouzi, M., Belghazi, T. and Moujjani, S. (2011) Semis et Plantations dans la Forêt de Chêne-liège de la Maâmora (Maroc). Forêt Méditerranéenne, 32, 301-314.

[29] Khalladi, S. (2013) Evaluation de l'effet de couvert arboré et arbustif sur le développement des plants et semis de chêne-liège ainsi que sur la strate herbacée dans la Maâmora.Memoire du 3ème Cycle, ENFI, Salé, Morocco. 